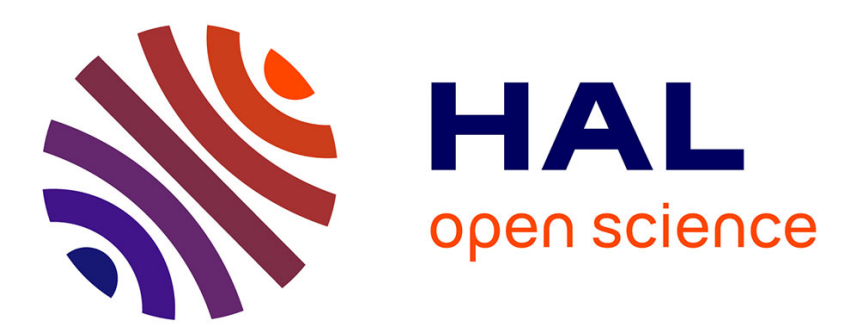

\title{
Changes In The Permeability, Streaming Potential And Resistivity Of A Claystone From The Nankai Prism Under Stress.
}

Laurence Jouniaux, Siegfried Lallemant, Jean-Pierre Pozzi

\section{- To cite this version:}

Laurence Jouniaux, Siegfried Lallemant, Jean-Pierre Pozzi. Changes In The Permeability, Streaming Potential And Resistivity Of A Claystone From The Nankai Prism Under Stress.. Geophysical Research Letters, 1994, 21,2, pp.149-152. 10.1029/93GL03293 . hal-00108298

\section{HAL Id: hal-00108298 \\ https://hal.science/hal-00108298}

Submitted on 11 Feb 2010

HAL is a multi-disciplinary open access archive for the deposit and dissemination of scientific research documents, whether they are published or not. The documents may come from teaching and research institutions in France or abroad, or from public or private research centers.
L'archive ouverte pluridisciplinaire HAL, est destinée au dépôt et à la diffusion de documents scientifiques de niveau recherche, publiés ou non, émanant des établissements d'enseignement et de recherche français ou étrangers, des laboratoires publics ou privés. 
This paper should be cited as : Jouniaux L., Lallemant S., and Pozzi J.-P.,

Changes in the permeability, streaming potential and resistivity of a claystone

from the Nankai prism under stress, Geophys. Res. Letters, 21, 149-152, 1994.

\title{
CHANGES IN THE PERMEABILITY, STREAMING POTENTIAL AND RESISTIVITY OF A CLAYSTONE FROM THE NANKAI PRISM UNDER STRESS.
}

\author{
Laurence Jouniaux, Siegfried Lallemant and Jean-Pierre Pozzi
}

Laboratoire de Géologie \& CNRS URA 1316, Ecole Normale Supérieure, France.

Abstract. Permeability is the critical factor governing fluid flow in accretionary prisms. Accretionary wedges are highly deformed, so permeability changes in an indurated claystone sample from the Nankai accretionary prism were measured during a triaxial stress experiment by the pulse decay method. Three zones were identified from the loading test. In zone I, the sample has deformed less than $1.3 \%$ and its permeability was $5.10^{-20} \mathrm{~m}^{2}$. In zone II, the deformation reached $1.5 \%$ and the permeability was unstable with time. In zone III, the sample deformation reached $2 \%$ and its permeability reached $3.810^{-18} \mathrm{~m}^{2}$. The permeability strongly decreased (from $3.210^{-18} \mathrm{~m}^{2}$ to $1.710^{-19} \mathrm{~m}^{2}$ ) with increasing effective pressure (from 2.3 to $10.8 \mathrm{MPa}$ ) after the sample was well deformed (zone III). The streaming potential was not measurable when the sample had a low permeability (zone I), but clearly occured when the permeability increased (zone III) : the streaming potential measured was $6 \mathrm{mV}$ when the pore pressure pulse applied was about $1.17 \mathrm{MPa}$ and the permeability $3.810^{-18} \mathrm{~m}^{2}$. Our experiments suggest that shear deformation under low effective pressure increased the vertical permeability of sediments above the décollement. This increase in permeability may be detected by measuring the streaming potential. Variations of flow rate of expelled fluid in accretionary wedges may be detected by monitoring changes of electrokinetic potential, giving new insights on the state of stress related to the seismic cycles.

\section{Introduction}

Elevated pore fluid pressure has long been recognized to maintain large parts of accretionary prisms near failure conditions [von Huene and Lee, 1982], resulting in complex interactions of strain regimes and fluid circulation. Expelled fluids from accretionary wedges have been shown to be transported from great depth within the prism [Moore and 
Vrolijk, 1992]. The use of Darcy's law as governing equation of fluid flow in a prism [Henry and Wang, 1991] is probably reasonable as the high density of interconnected fractures probably approximates a Darcian continuum over large length scales. As expressed by Darcy's law, fluid pressure gradients are the driving force of fluid flow while rock permeability resists fluid flow. Pressure gradients change less than 1 order of magnitude, although permeability changes can be of 6 to 8 orders of magnitude [Moore and Vrolijk, 1992]. The permeability is thus the critical factor governing fluid flow in accretionary wedges. We present results from an experimental study of the changes of permeability associated with the deformation of an indurated claystone sample from the Nankai accretionary wedge. The permeability was measured as a function of the effective pressure for different states of axial strain. Variation of the electrical resistivity was measured during the experiment. We also measured the streaming potential during the measurement of permeability by pore pressure diffusion.

\section{Sampling and experimental procedure}

The two samples studied were obtained from leg 131 (hole 808C) of the Ocean Drilling Program, in the Nankai accretionary wedge. One sample was a tuff (sample 131808C-54R-1, 68-72cm), collected from about 810 meters below the sea floor (mbsf), and the other was an indurated claystone (sample 131-808C-102R-1,121-126 cm), from about 1260 mbsf, with porosity of $23 \%$ and bulk density of $2.4 \mathrm{~g} / \mathrm{cm}^{3}$. Both samples were from below the décollement and thus belong to an undeformed sequence [Taira et al., 1992]. Samples were cut into cylinders : $20 \mathrm{~mm}$ in diameter and $40 \mathrm{~mm}$ long. They were saturated with distilled water and isolated from the confining pressure by a jacket. We used a press with controlled displacement. Variations of axial pressure, confining pressure and pore pressure were independant. Samples were first subjected to an axial stress and a confining pressure of $11 \pm 0.1 \mathrm{MPa}$, and a pore pressure of $9 \pm 0.1 \mathrm{MPa}$. These values were raised after a period of time sufficient to nearly equilibrate the pore pressure due to diffusion.

Vertical permeability was determined by the pulse decay method [Brace et al., 1968], which follows the decay of a small step change of pore pressure imposed at one end of a sample. When a pressure pulse $\Delta \mathrm{P}_{0}$ (less than $10 \%$ the magnitude of the total pore pressure) is generated, the 
differential pressure $\Delta \mathrm{P}(\mathrm{t})$ decays exponentially as a function of time, $t$ :

$$
\Delta \mathrm{P}(\mathrm{t})=2 \Delta \mathrm{P}_{0} \mathrm{~V}_{2} /\left(\mathrm{V}_{1}+\mathrm{V}_{2}\right) \mathrm{e}^{-\mathrm{mt}}
$$

where $\mathrm{V}_{1}$ and $\mathrm{V}_{2}$ are the upstream and downstream reservoir volumes $\left(\mathrm{V}_{1}=\mathrm{V}_{2}=5010^{-6} \mathrm{~m}^{3}\right.$ in our experimental setup, large compared with the sample pore volume which is $2.910^{-6} \mathrm{~m}^{3}$ ), $\mathrm{t}$ is time and $\mathrm{m}$ is a decay time constant. Plotting the decay curve in terms of $\ln (\Delta \mathrm{P}(\mathrm{t}))$ versus time $\mathrm{t}$ yields a straight line having a slope $\mathrm{m}$, and the permeability $\mathrm{k}$, can be determined by $\mathrm{k}=\left(\mathrm{m} \mu \beta \mathrm{L} \mathrm{V} \mathrm{V}_{2}\right) /\left(\mathrm{A}\left(\mathrm{V}_{1}+\mathrm{V}_{2}\right)\right)$ where $L$ is the length of the sample, $A$ the cross-sectional area of the sample, $\mu$ the dynamic viscosity of pore fluid at temperature measurement $\left(10^{-3} \mathrm{~Pa}\right.$.s at $\left.20^{\circ} \mathrm{C}\right)$, and $\beta$ is the compressibility of the pore fluid $\left(0.4210^{-9} \mathrm{~Pa}^{-1}\right)$. The pulse decay method is time-consuming because the diffusion of the pressure pulse across a clay sample can be about 24 hours and we must wait at each step for the total diffusion of the pore pressure inside the sample. Our apparatus was tested by measuring the permeability to water of a sample of Fontainebleau sandstone (France) with a porosity of $4.3 \%$ and a permeability to air of $410^{-16} \mathrm{~m}^{2}$, giving us the opportunity to measure the permeability to water using two different methods. We found $\mathrm{k}=2.210^{-16} \mathrm{~m}^{2}$ with the steady state flow method and $\mathrm{k}=1.110^{-16} \mathrm{~m}^{2}$ with the pulse decay method, and concluded that our experimental method and the use of (1) yield reliable values of the permeability.

The pulse decay method has been used in triaxial tests on granite [Brace et al., 1968, Bernabé, 1987], and on samples of tuff [Zhang et al., 1993]. But permeability of argillaceous rocks is generally measured using a consolidation test [Taylor and Fisher, 1993]. Because the permeability of clays is supposed to be sensitive to the effective pressure [Brace, 1980], we made measurements of permeability at different states of effective stress.

The resistivity of the samples was measured at $4 \mathrm{kHz}$ with an impedancemeter. The streaming potential is the difference of potential across a sample when a fluid is made to flow through it by a driving pressure $\Delta \mathrm{P}$. This streaming potential was measured by a voltmeter with an input resistance greater than $10^{10} \Omega$.

\section{Experimental results}

\section{$\underline{\text { Permeability measurements }}$}


The sample of tuff had a permeability of $3.5 \pm 1.510^{-20}$ $\mathrm{m}^{2}$ (or $3.510^{-11} \mathrm{~cm} / \mathrm{s}$ ) when subjected to an axial stress and a constant confining pressure of $11 \mathrm{MPa}$, and a pore pressure of $9.2 \mathrm{MPa}$. Unfortunately, this sample was crushed because of a power cut and we could not make further measurements.

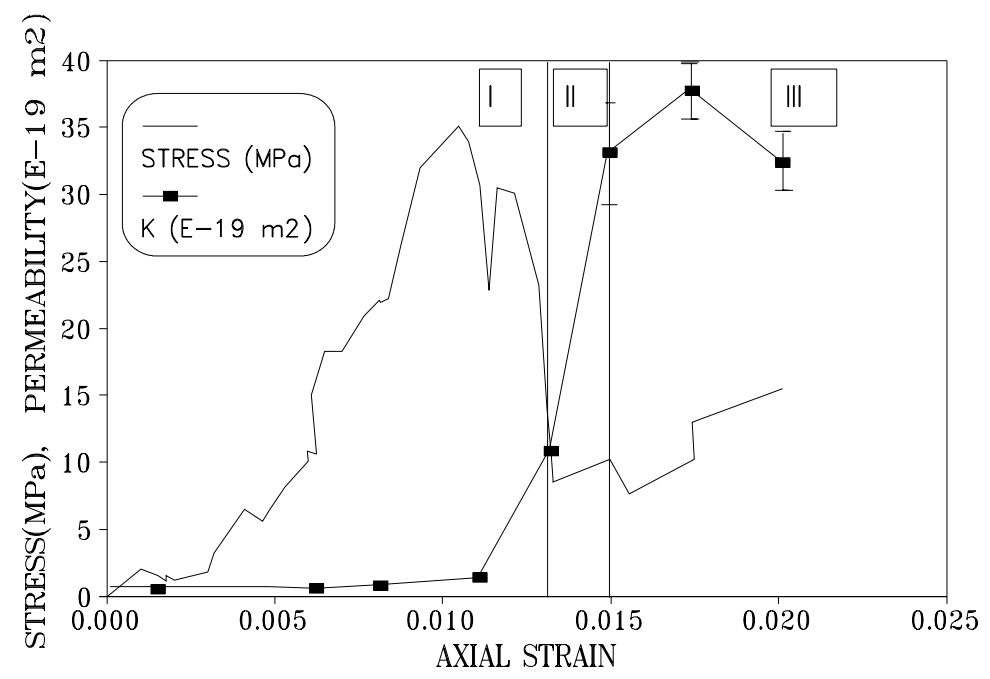

Fig. 1. : Differential stress (continuous line) and permeability as a function of axial strain (square dots). Zone II represents a critical strain where the permeability is unstable. Permeability changes from $510^{-20} \mathrm{~m}^{2}$ to $3.810^{-18}$ $\mathrm{m}^{2}$ in a narrow range of axial stress.

The second sample was exposed to an increasing deviatoric stress, with a confining pressure of $12 \mathrm{MPa}$, and a pore pressure of $9.2 \mathrm{MPa}$. The entire experiment lasted 11 days and the sample was deformed at an average strain rate of $2.310^{-8} \mathrm{~s}^{-1}$. The timing of the measurements was kept as constant as possible. The differential stress (axial stress minus confining pressure) and the permeability as a function of the axial strain are represented in Figure 1. First, the permeability was $510^{-20} \mathrm{~m}^{2}$, and remained almost constant up to the stress drop (Zone I). This stress drop, from $35 \mathrm{MPa}$ to $10 \mathrm{MPa}$, occured during a 49 hours period. Then the permeability increased up to 1.1 and $3.310^{-18} \mathrm{~m}^{2}$ (Zone II) and remained high : 3.2 to $3.810^{-18} \mathrm{~m}^{2}$ when the sample was further deformed (Zone III). Zone II represents a critical deformation where the permeability was unstable. At the Zone I-II transition, two measures of permeability were made at constant axial strain : it decreased with time from $210^{-18} \mathrm{~m}^{2}$ to $1.210^{-18} \mathrm{~m}^{2}$ as shown in Figure 2 . At 
the Zone II-III transition, permeability increased with time from $1.810^{-18} \mathrm{~m}^{2}$ to $3.310^{-18} \mathrm{~m}^{2}$. The time needed for each measure of permeability is shown by horizontal line.

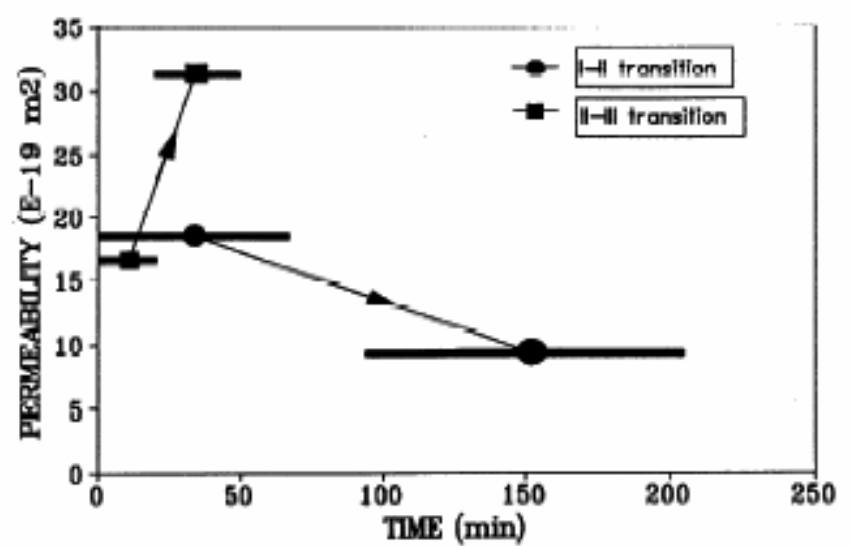

Fig. 2. : Evolution of the permeability with time at the I-II and II-III transitions (Fig.1.). The time needed for a permeability measurement is shown by horizontal line.

Fig. 2. : Evolution of the permeability with time at the I-II and II-III transitions (Fig.1.). The time needed for a permeability measurement is shown by horizontal line.

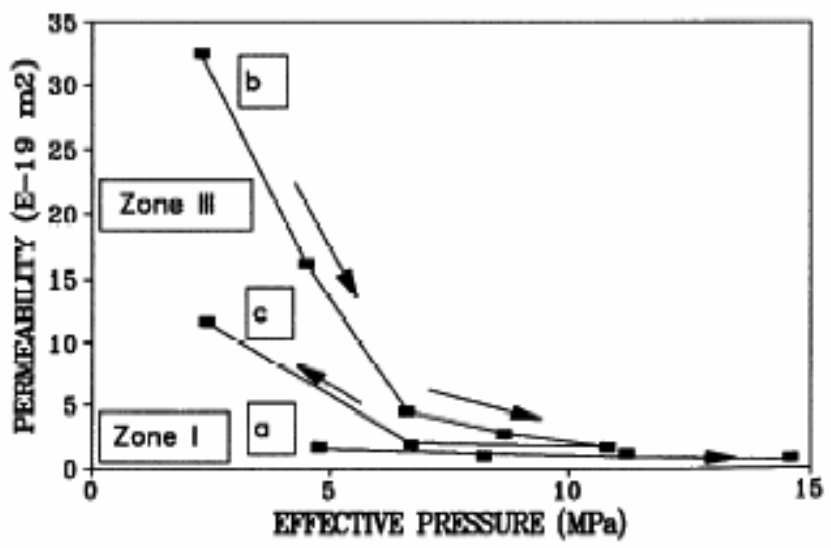

Fig. 3. : Permeability versus the effective pressure. a- in zone I, b- in zone III, by increasing confining presure; c- in zone III, by increasing pore pressure.

The permeability was then measured as a function of the effective pressure (confining pressure minus pore pressure) between 2 and $15 \mathrm{MPa}$. In zone I the permeability did not vary with the effective pressure as shown in Figure 3. On the other hand the permeability in zone III (after the last permeability measurement shown in Figure 1) became very 
sensitive to the effective pressure : the permeability decreased from $3.210^{-18} \mathrm{~m}^{2}\left(\mathrm{P}_{\mathrm{e}}=2.3 \mathrm{MPa}\right)$ to $1.710^{-19} \mathrm{~m}^{2}$ $\left(\mathrm{P}_{\mathrm{e}}=10.8 \mathrm{MPa}\right)$. When the effective pressure was decreased by an increase of pore pressure to $\mathrm{P}_{\mathrm{e}}=2.3 \mathrm{MPa}$, the permeability increased but did not recover its initial value (3.2 $10^{-18} \mathrm{~m}^{2}$ ). At the end of the experiment, no macroscopic shear fracture was observed. For this clay sample, the well-oriented clay flakes deformed by shear stress probably produced interconnected fluid volumes, resulting in an increase of permeability.

\section{$\underline{\text { Electrical measurements }}$}

The resistivity decreased during the first stage of deformation, then it increased in zone II and III as shown in Figure 4. For this sample, the electrical conductivity was due not only to electrolytic conduction, but also to the surface conductivity. Moreover, the electrical conductivity of the fluid changed through chemical interaction during the 10 days of the experiment from $1500 \Omega$.m (initial saturating fluid) to $90 \Omega$.m at the end of the experiment (determined from collected water when the sample was taken off the cell), resulting in a complex behavior of the resistivity with the deformation. This behavior is opposite to that observed in sandstones, whose mechanical behavior is brittle with dilatancy, and whose electrical conductivity is only due to the electrolytic conduction [Jouniaux et al., 1992].

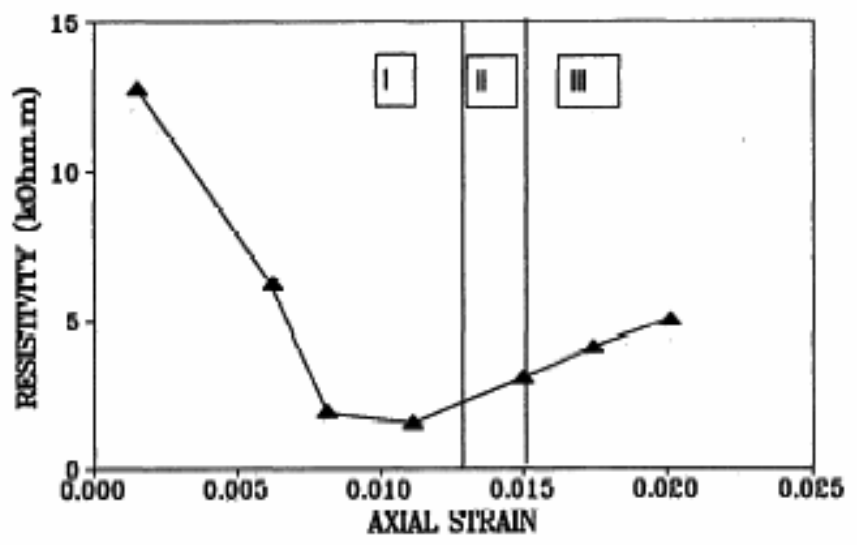

Fig. 4. : Electrical resistivity of the rock versus axial strain. The behavior of the resistivity includes the electrolytic conduction, the surface conductivity, and the chemical interaction. 


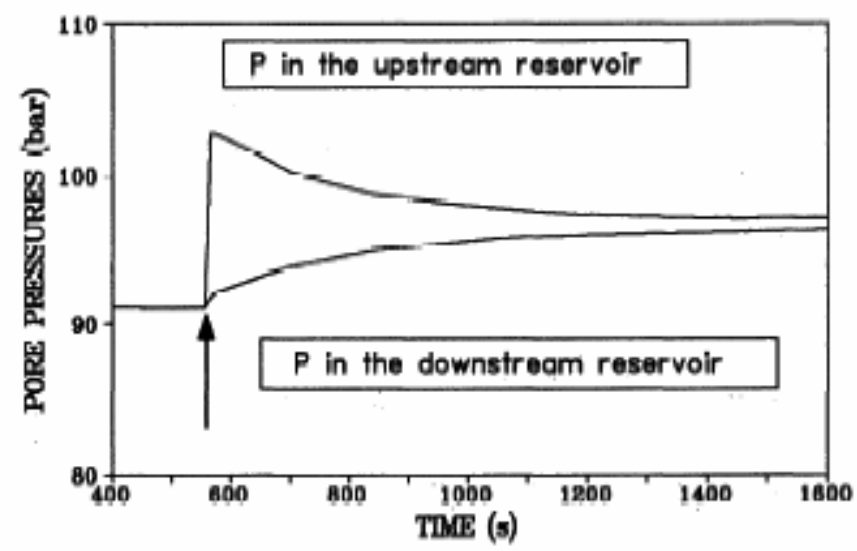

Fig. 5a. : Pulse decay as a function of time measured at maximum permeability. The arrow indicates the timing of the applied pressure pulse.

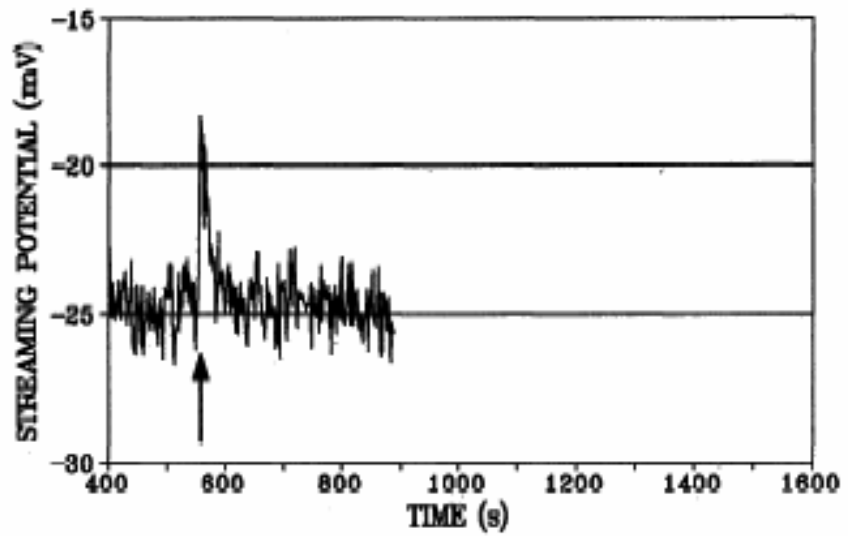

Fig. 5b. : Streaming potential as a function of time. The streaming potential only occured in Zone III of strain (Fig.1) when the pore pressure pulse was just applied. The permeability of the sample was $3.810^{-18} \mathrm{~m}^{2}$. The arrow indicates the timing of the applied pressure pulse.

The streaming potential was not measurable when the sample had a low permeability (zone I), but clearly occured when the permeability increased (zone III). As shown in Figures $5 \mathrm{a}$ and $5 \mathrm{~b}$, electrical noise was recorded before the pore pressure pulse $\Delta \mathrm{P}_{\mathrm{O}}$ was applied and during the diffusion of the pore pressure. The streaming potential occured just when the pore pressure pulse was applied. For this example, $\Delta \mathrm{P}_{0}$ is $11.7 \mathrm{bar}$, the streaming potential was 6 $\mathrm{mV}(-25 \mathrm{mV}$ to $-19 \mathrm{mV})$ while the noise was $2.5 \mathrm{mV}$. The same phenomenon was observed in the next state of deformation studied, when permeability was $3.210^{-19} \mathrm{~m}^{2}$ (the last point in Figure 1). The streaming potential, 
produced by fluid percolation when a fluid is made to flow through a porous medium, is theoretically proportional to the driving pore pressure [Overbeek, 1952; Nourbehecht, 1963; Dukhin and Derjaguin, 1974; Morgan et al., 1989]. $\mathrm{C}=\Delta \mathrm{V} / \Delta \mathrm{P}=-(\varepsilon \zeta) /(\eta \sigma)$ is called the electrokinetic coupling coefficient and depends on the fluid conductivity $\sigma$, the fluid viscosity $\eta$, the zeta potential $\zeta$ (potential at the rock/fluid interface), and the dielectric constant of fluid $\varepsilon$.

When the permeability of a sample is less than $10^{-17} \mathrm{~m}^{2}$, the transient flow is described by a pressure diffusion law [Brace, 1968], and the volume flowing in the sample is the storage of fluid, due to the compressibilities of the fluid and of the solid. The evolution of the streaming potential with time is

$$
\Delta \mathrm{V}(\mathrm{t})=\frac{1}{\sigma} \cdot \int_{\mathrm{x}_{1}}^{\mathrm{x}_{2}} \mathrm{i}_{\text {conv }}(\mathrm{t}) \mathrm{dx} \text {, where } \mathrm{i}_{\text {conv }}(\mathrm{t})=\frac{\mathrm{C} \sigma \partial \mathrm{P}(\mathrm{t})}{\partial \mathrm{x}}
$$

and $\mathrm{x}_{2}-\mathrm{x}_{1}$ is the length of the sample. If we assume that $\mathrm{C}$ is constant, $\Delta \mathrm{V}(\mathrm{t})=\mathrm{C} \Delta \mathrm{P}(\mathrm{t})$, the pressure gradient being constant along the length of the sample although it varies with time. The maximum streaming potential occurs when the pore pressure pulse $\Delta \mathrm{P}$ is maximum. The streaming potential strongly decreased and was no longer measurable when $\Delta \mathrm{P}$ fell below a critical value of 8 bar in our example. $\Delta \mathrm{V}$ and $\Delta \mathrm{P}$ showed two different time constants, $40 \mathrm{~s}$ and $165 \mathrm{~s}$ respectively, defined as the time when the signal decreased to half of its initial value. When $\Delta \mathrm{P}_{0}$ was applied, the Darcy's speed was $3.5 \mathrm{~m} / \mathrm{an}$, whereas it was $2.4 \mathrm{~m} / \mathrm{an}$ when $\Delta \mathrm{P}$ fell to this critical value. It seems that the volume flowing in the sample was not sufficient to produce a measurable streaming potential, as when a decrease in the permeability of a sample of sandstone induces a decrease in the electrokinetic coupling coefficient [Pozzi and Jouniaux, 1993].

\section{Discussion and conclusion}

The permeability of the indurated claystone increased almost by two orders of magnitude (from $510^{-20} \mathrm{~m}^{2}$ to 3.8 $10^{-18} \mathrm{~m}^{2}$ ) when exposed to a deviatoric stress, even at small strain (0.015). We observed an unstable zone (zone II) where the permeability was unstable with time, at the same strain and without noticeable stress relaxation. When the sample was further deformed, the permeability remained high. Permeability showed only a slight variation with 
effective pressure at low axial strain and became very sensitive to the effective pressure at greater axial strain (from $3.210^{-18} \mathrm{~m}^{2}$ to $1.710^{-19} \mathrm{~m}^{2}$ ) in the range of effective pressure from 2.3 to $10.8 \mathrm{MPa}$. The streaming potential became measurable in Zone III. At a permeability greater than $310^{-18} \mathrm{~m}^{2}$, a $6 \mathrm{mV}$ streaming potential was produced in response to a pressure pulse of $1.17 \mathrm{MPa}$.

Although performed on only one sample, progressive shear deformation of an initially underformed sample from below the décollement is intended to approximate what happens to sequences of similar lithology that are naturally deformed above the décollement. Based on the geometry of the brittle structures in hole 808C, Lallemant et al. [1993] proposed that the $200 \mathrm{~m}$ thick deformed claystone from above the décollement was subjected to high pore fluid pressure. Our experiments suggest that a shear strain under low effective pressure may be the cause of increased vertical permeability of these hemipelagic sequences. This increase of permeability may be detected by measuring the streaming potential. The streaming potential will be enhanced in cases of fresh water circulation relative to sea water circulation, because of the greater resistivity of fresh water. Changes of flow rates of fluids expelled from an accretionary wedge could be detected by monitoring changes of electrokinetic potential, as proposed by Boulègue et al. [1985], and related to the state of stress and the seismic hazard.

Acknowledgments : We thank P. Henry for fruitful discussions. This study is a collaboration with ENSAM (laboratoire de mécanique des structures). This research was supported by ANDRA, the GRECOgéomateriaux and INSU-Océanoscope. This is ENS contribution 309 and CNRS-INSU-DBT contribution 662, thème instabilités.

\section{References}

Bernabé, Y., The effective pressure law for permeability during pore pressure and confining pressure cycling of several crystalline rocks, J. Geophys. Res., 92, 649-657, 1987.

Boulègue, J., Le Pichon, X., and Iiyama, J.T., Earthquake prediction in Tokaï area (Japan), C. R. Acad. Sc. Paris, t. 301, Série II, n¹6, 1217-1219, 1985.

Brace, W.F., Walsh, J.B., and Frangos, W.T., Permeability of granite under high pressure, J. Geophys. Res., 으, 22252236, 1968. 
Brace, W.F., Permeability of crystalline and argillaceaous rocks, Int. J. Mech. Min. Sci. and Geomech. Abstr., 17, 241-251, 1980.

Dukhin, S.S., and Derjaguin, B.V., Surface and Colloïd Science, vol. 7, edited by E. Matijevic, John Wiley \& Sons, New York, 1974.

Henry, P., and Wang, C.-Y., Modeling of fluid flow and pore pressure at the toe of the Oregon and Barbados accretionary wedges, J. Geophys. Res., $\underline{96}$, 20,109-20,130, 1991.

Jouniaux, L. et al., Resistivity changes induced by triaxial compression in saturated Sandstones from Fontainebleau, C. R. Acad. Sci. Paris, t. 315, Série II, 1493-1499, 1992.

Lallemant, S.J., et al., Stress tensors at the toe of the Nankai accretionary prism : an application of inverse methods to slickenlined faults, Proceedings of the Ocean Drilling Program, Scientific Results, 131, 103-122, 1993.

Moore, J.C. and Vrolijk, P., Fluids in Accretionary Prisms, Reviews of geophysics, 30,2, 113-135, 1992.

Morgan, F. D., et al., Streaming potentials properties of Westerly granite with applications, J. Geophys. Res., $\underline{94}$ 12449-12461, 1989.

Nourbehecht, B., Irreversible thermodynamic effects in inhomogeneous media and their applications in certain

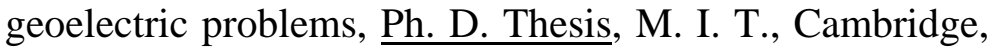
Massachussetts, 1963.

Overbeek, J.Th.G., Colloïd Science, vol 1, edited by H.R. Kruyt, Elsevier, 115-193, 1952

Pozzi, J. P., and Jouniaux, L., Electrical effects of fluid circulation in sediments and seismic prediction, $\underline{C}$. R. Acad. Sci. Paris, 1993, in press.

Reynolds, S.J. and Lister, G.S., Structural aspects of fluidrock interaction in detachment zones, Geology, 15, 362366, 1987.

Taira, A. et al., Sediment deformation and hydrogeology of the Nankai Trough accretionary prism : Synthesis of shipboard results of ODP Leg 131, Earth and Planetary Science Letters, 109, 431-450, 1992.

Taylor, E., and Fisher, A., Sediment permeability at the Nankai accretionary prism, site 808, Proceedings of the Ocean Drilling Program, Scientific Results, 131, 235-245, 1993.

von Huene, R., and Lee, H., The possible signifiance of pore fluid pressure and subduction zones, Studies of Continental Margin Geology,_Am. Assoc. Pet. Geol. Mem., 34, 781-791, 1982.

Zhang, J., Davis, D.M., and Wong, T.-F., Failure modes of tuff samples from leg 131 in the Nankai accretionary 
wedge, Proceedings of the Ocean Drilling Program,

Scientific Results, 131, 275-281, 1993.

L. Jouniaux, S. Lallemant and J-P Pozzi, Laboratoire de Géologie \& CNRS URA 1316, Ecole Normale Supérieure, 24 rue Lhomond, 75231 Paris Cedex 05, France.

Jouniaux et al. : Permeability and Streaming Potential of a Nankai Claystone under Stress 